\title{
MALIGNANT HYPERTHERMLA: A DISEASE OF SPECIFIC MYOFIBER TYPE?
}

\author{
Thomas E. Nelson and Sydney S. Schochet, JR.
}

\begin{abstract}
The present study attempts to determine if malignant hyperthermia susceptibility (MHS) is limited to muscles composed predominantly of a single major fiber type. The MHS trapezius muscle ( 49 per cent type 1 and 51 per cent type 2 fibers) has greater abnormal contracture response to halothane or to caffeine than does MHS gracilis (11 per cent type 1 and 80 per cent type 2 fibers). The dynamic properties (contraction and relaxation times) of MHS trapezius and MHS gracilis are similar, suggesting that the greater contracture response of MHS trapezius to halothane or to caffeine is more biochemical than physiological in origin. The results of this study are discussed in relevance to the diagnosis and to aetiologic investigation of malignant hyperthermia.
\end{abstract}

KEY WORDS: HYPERTHERMIA, malignant.

Malignant hyperthermia is a catastrophic occurrence during general anaesthesia in genetically predisposed individuals. ${ }^{1,2}$ The hypermetabolic state, rapid increase in body temperature and other associated pathophysiological events are probably the consequence of an underlying skeletal muscle defect. ${ }^{3-5}$ Skeletal muscle from the malignant hyperthermia susceptible (MHS) man and pig is characterized by abnormal metabolic and contracture responses in vitro. 6.7 These abnormal in vitro contracture responses provide a basis for diagnostic ${ }^{8,9}$ aetiological ${ }^{10-12}$ and genetic ${ }^{13,14}$ investigations.

One seemingly important aspect of the pathophysiology of malignant hyperthermia that has not been investigated adequately is whether the disease is limited to a specific muscle fiber type. Although considerable ambiguity exists regarding classification of skeletal muscle fibers, it is clear that the metabolic and contractile properties of skeletal muscle are differentiated into specific fiber types. ${ }^{15,16}$ It is generally accepted that fibers may be fast, slow, or intermediate in contraction times, and may be profiled biochemically regarding the extent of aerobic or glycolytic metabolism. ${ }^{17}$ In certain animal species it is possible to demonstrate marked differences in proportion of fiber types among muscles, where-

Thomas E. Nelson, Ph.D., Department of Anesthesiology, The University of Texas Medical Branch Galveston, Texas 77550, U.S.A.; Sydney S Schochet, Jr., M.D., Department of Pathology, West Virginia University Medical Center, Morgantown, West Virginia 26506, U.S.A.

Can. Anaesth. Soc. J., vol. 29, no. 2, March 1982 as in man most normal skeletal muscles are a uniform mixture of fiber types.

What relationship, if any, a specific fiber type or the relative proportions of fiber types may have to the abnormalities of MHS muscle is unknown. The availability of a porcine animal model for malignant hyperthermia provides a means of comparing different muscle types. In the present experiment, the hypothesis tested is that the in vitro contracture response of MHS and normal skeletal muscle is a function of the contractile and biochemical profile as dictated by fiber type differentiation. Comparisons are made between muscles from MHS and normal pigs.

\section{Methods}

Ten purebred MHS Poland China pigs and five mixed breed ( $\frac{1}{2}$ Landrace, $\frac{1}{4}$ Yorkshire, $\frac{1}{d}$ Hampshire) littermate pigs resistant to a halothane plus succinylcholine challenge were utilized. Biopsies from the trapezius and gracilis muscles were obtained by methods previously described. ${ }^{10}$ Methods for measuring isometric contracture response of pig muscle exposed to caffeine and to halothane were previously described. ${ }^{8}$

Assessments of certain dynamic properties of the muscle strips were made as follows. Tetanus tension was determined by applying a stimulation of $60 \mathrm{~Hz}$ for several seconds. The frequency of stimulation which fused the twitch response into an unrelaxed, subtetanus tension was determined in the following way. A train of stimuli 163 
TABLE I

Dynamic Properties of Trapezius and Gracilis Muscle From Control AND MHS PIGS

\begin{tabular}{|c|c|c|c|c|c|c|c|}
\hline \multirow[b]{3}{*}{ Wt., mg } & \multicolumn{4}{|c|}{ MHS } & \multicolumn{3}{|c|}{ Control } \\
\hline & \multicolumn{2}{|c|}{ Gracilis } & \multicolumn{2}{|c|}{ Trapezius } & \multicolumn{2}{|c|}{ Gracilis } & Trapezius \\
\hline & $\begin{array}{l}138 \\
(42)\end{array}$ & $\pm 60^{*}$ & $\begin{array}{l}155 \\
(42)\end{array}$ & $=49$ & $\begin{array}{l}118 \\
(42)\end{array}$ & \pm 43 & $\begin{array}{l}137 \\
(48)\end{array}$ \\
\hline In, mm & $\begin{array}{l}31.2 \\
(19)\end{array}$ & \pm 5 & $\underset{(20)}{28.9} \quad \pm$ & $=8$ & $\underset{(42)}{28.6} \pm$ & \pm 5 & $\underset{(48)}{28.0}=6$ \\
\hline Twitch/Tetanus & $(4)^{0.190 \pm}$ & \pm 0.03 & ${ }^{0.180 \pm}$ & $=0.03$ & (9) $0.179 \pm$ & \pm 0.04 & $(5)^{0.362 \pm 0.13}$ \\
\hline Fusion Frequency, $\mathrm{Hz}$ & $\begin{array}{l}22.9 \\
(14)\end{array}$ & \pm 2.2 & $\begin{array}{l}21.1 \\
(14)\end{array}$ & $=2.4$ & $\begin{array}{l}22.9 \\
(13)\end{array}$ & \pm 2.7 & $\underset{(12)}{21.0} \pm 2.3$ \\
\hline
\end{tabular}

*Value is mean \pm standard deviation of mean. Numbers in parentheses represent number of muscle strips tested.

was applied every 10 seconds for a duration of two seconds. A first stimulus was applied at $2 \mathrm{~Hz}$ and was increased by $2 \mathrm{~Hz}$ between each stimulus train up to a final frequency of $30 \mathrm{~Hz}$. The data were statistically evaluated by analysis of variance for main effects and by the Student's t-test for mean comparisons.

Individual twitch kinetics of the MHS muscle preparations were measured from photographs of single twitch responses displayed on a fast sweeping storage oscilloscope. Contraction time was measured by the time from initial tension development to the tension peak. Relaxation time was measured from peak of tension to return of 50 per cent of initial baseline tension.

Frozen sections of MHS muscle were prepared and stained by standard hematoxylin-eosin, modified trichrome, nicotinamide adenine dinucleotide tetrazolium reductase (NADH-TR) and myofibrillar adenosine triphosphatase (ATPase, $\mathrm{pH} 9.4$ and 4.3 ) techniques. Photographs of the ATPase preparations at $\mathrm{pH} 9.4$ were used to determine the number and relative proportions of the type 1 and type 2 myofibers. No attempt was made to subtype either the type 1 or type 2 myofibers.

\section{Results}

\section{Histological Classification}

Gracilis muscle from MHS pigs contained 11 \pm 5 per cent type 1 fibers and $89 \pm 5$ per cent type 2 fibers. In comparison, MHS trapezius is composed of $41 \pm 10$ per cent type 1 and $59 \pm 10$ per cent type 2 fibers. The high percentage of type 2 fibers in gracilis muscle represents a dominant anaerobic metabolic function. In contrast, trapezius muscle has approximately equal proportions of type 1 and type 2 fibers and may be identified as intermediate in metabolic profile.

\section{Dynamic Properties of Control and MHS Muscle}

No difference is detected among MHS and control muscles for the length, weight, or the frequency of stimulation which fuses the twitch response $(\mathrm{P}<0.05$, Table I). Furthermore, no significant difference is found among these variables when trapezius responses are compared to gracilis responses within the MHS and control groups $(\mathrm{P}<0.05$, Table $\mathrm{I})$. Individual twitch dynamics for MHS muscle including contraction time and time to 50 per cent relaxation are presented in Table II.

\section{Pharmacological Responses}

Trapezius and gracilis muscle from the MHS pigs have marked contracture response to halothane (Table II). In contrast, control pig muscle produces little or no contracture response to halothane (data not shown). Halothane produced greater contracture in MHS trapezius compared with MHS gracilis $(p<0.05$, Table II).

Caffeine produces contracture in both MHS and control pig muscle. The MHS gracilis and trapezius muscle undergo contracture when a caffeine concentration of 1 and $0.5 \mathrm{mM}$ respectively is added (Table III). In comparison, control gracilis and trapezius have contractures initiated by 4 and $8 \mathrm{mM}$ caffeine respectively 
TABLE II

Contracture Response to $1 \%$ and $3 \%$ Halothane in Trapezius and Gracilis Muscle from MHS Pigs

\begin{tabular}{|c|c|c|c|c|}
\hline \multirow[b]{2}{*}{ Muscle } & \multirow[b]{2}{*}{$\begin{array}{l}\text { Contraction } \\
\text { Time, msec }\end{array}$} & \multirow[b]{2}{*}{$\begin{array}{l}50 \% \text { Relax. } \\
\text { Time, msec }\end{array}$} & \multicolumn{2}{|c|}{ Isometric Contracture, $\mathbf{g}$} \\
\hline & & & $\begin{array}{l}\text { Halothane } \\
1.0 \text { per cent }\end{array}$ & $\begin{array}{l}\text { Halothane } \\
3.0 \text { per cent }\end{array}$ \\
\hline Gracilis & $82.7 \pm \frac{ \pm}{(6)} 4.8^{*}$ & $129 \pm \frac{11}{(6)}$ & $\begin{array}{c}0.61 \pm 0.3 \\
(18)\end{array}$ & $\begin{array}{c}3.72 \pm 1.6 \\
(6)\end{array}$ \\
\hline Trapezius & $88.7 \pm 10.3$ & $147 \pm 23$ & $\begin{array}{c}2.29 \pm 1.3 \\
(18)\end{array}$ & $\begin{array}{c}6.30 \pm 2.3 \\
(6)\end{array}$ \\
\hline
\end{tabular}

*Values are means \pm standard deviation of mean; values in parenthesis are number of muscles tested.

TABLE III

Cumulative Caffeine-Induced Contracture in Trapezius and Gracilis Muscle from MHS and Control Pigs

\begin{tabular}{|c|c|c|c|c|c|c|}
\hline \multirow[b]{3}{*}{ Controls } & \multicolumn{6}{|c|}{ Cumulative Contracture, $\mathrm{g}$} \\
\hline & \multicolumn{2}{|c|}{ Caffeine, mM: } & \multirow[b]{2}{*}{2.0} & \multirow[b]{2}{*}{4.0} & \multirow[b]{2}{*}{8.0} & \multirow[b]{2}{*}{16.0} \\
\hline & 0.5 & 1.0 & & & & \\
\hline Gracilis & $\begin{array}{l}0^{*} \\
(14)\end{array}$ & $\begin{array}{l}0 \\
(14)\end{array}$ & $\begin{array}{l}0 \\
(14)\end{array}$ & $\begin{array}{l}0 \\
(14)\end{array}$ & $\begin{array}{l}0.62 \pm 0.56 \\
(14)\end{array}$ & $\underset{(14)}{2.55} \pm 1.3$ \\
\hline Trapezius & $\begin{array}{l}0 \\
(16)\end{array}$ & $\begin{array}{l}0.01 \\
(16)\end{array}$ & $\begin{array}{l}0.04 \pm 0.10 \\
\text { (16) }\end{array}$ & $\begin{array}{l}0.75 \pm 0.76 \\
(16)\end{array}$ & $\begin{array}{l}4.46 \pm 1.6 \\
(16)\end{array}$ & $\begin{array}{c}7.9 \\
(10)\end{array}$ \\
\hline \multicolumn{7}{|l|}{ MHS } \\
\hline Gracilis & $\begin{array}{l}0 \\
(20)\end{array}$ & $\begin{array}{l}0.17 \pm 0.25 \\
(20)\end{array}$ & $\begin{array}{l}0.96 \pm 0.54 \\
(20)\end{array}$ & $\begin{array}{l}2.3 \pm 0.92 \\
(20)\end{array}$ & $\begin{array}{l}3.3 \pm 1.3 \\
(14)\end{array}$ & $\begin{array}{l}10.5 \\
(10)\end{array}$ \\
\hline Trapezius & $\begin{array}{l}0.22 \pm 0.45 \\
(19)\end{array}$ & $\begin{array}{l}0.80 \pm 0.67 \\
\text { (19) }\end{array}$ & $\begin{array}{l}2.84 \pm 1.3 \\
(18)\end{array}$ & $\begin{array}{l}5.2 \\
(18)\end{array}$ & $\begin{array}{l}6.4 \pm 2.2 \\
(12)\end{array}$ & $\frac{17.2}{(8)} \pm 6.7$ \\
\hline
\end{tabular}

*Values are means \pm standard deviation of mean; values in parentheses are number of muscles tested.

(Table III). Stated in another way, the contracture-caffeine dose response curve for MHS muscle falls to the left of control values. The contracture response of MHS trapezius muscle to caffeine is greater than MHS gracilis at each concentration tested ( $p<0.05$, Table III). Likewise, the control trapezius muscle contracture response to each caffeine dose is greater ( $p$ $<0.05$ ) than control gracilis (Table III).

The presence of halothane markedly potentiates the contracture response of MHS and control muscle to caffeine. Compared to MHS gracilis, MHS trapezius had greater $(p<0.05)$ contracture response to each caffeine dose in the presence of one percent halothane except at $1 \mathrm{mM}$ caffeine where the difference was not significant (Table IV). Control trapezius has greater contracture response to caffeine ( $p<0.05$ ), than does control gracilis, when one percent halothane is present (Table IV). At the lower caffeine concentrations $(0.5-2 \mathrm{mM})$, the contracture response of control trapezius cannot be distin- guished from the MHS muscle responses when halothane is present (Table IV).

\section{Discussion}

The abnormal contracture responses of MHS trapezius muscle exposed to halothane or to caffeine is greater than those for MHS gracilis muscle. Based on the dynamic properties of contraction and relaxation times, trapezius and gracilis muscle have similar physiological makeup. The major difference between trapezius and gracilis muscle appears to have a biochemical basis as assessed by histological techniques. The gracilis muscle is comprised mainly of type 2 fibres while the trapezius has almost equal proportions of type 1 and type 2 fibres. On this basis, it may be speculated that the greater contracture response of MHS trapezius muscle, compared to gracilis, is a function of the greater percentage of type 1 fibers. Consequently, MHS may be a feature of type 1 muscle fibers. The fact 
TABLE IV

Cumulative 1\% Halothane Plus Caffeine-Induced Contracture in Trapezius and Gracilis Muscle from MHS and Control. Pigs

\begin{tabular}{|c|c|c|c|c|c|}
\hline \multirow[b]{3}{*}{ Controls } & \multicolumn{5}{|c|}{ Cumulative Contracture, $\mathrm{g}$} \\
\hline & \multicolumn{4}{|c|}{$1 \%$ Halothane + Caffeine, $\mathrm{mM}:$} & \multirow[b]{2}{*}{4} \\
\hline & 0.25 & 0.5 & 1 & 2 & \\
\hline Gracilis & $\begin{array}{l}0 \\
(10)\end{array}$ & $\begin{array}{l}0.08 \pm 0.1 \\
(10)\end{array}$ & $\begin{array}{l}0.13 \pm 0.16 \\
(10)\end{array}$ & $\begin{array}{l}1.2 \pm 0.57 \\
(10)\end{array}$ & $\underset{(10)}{3.6 \pm 0.64}$ \\
\hline Trapezius & $\begin{array}{l}0 \\
(12)\end{array}$ & $\begin{array}{l}0.31 \\
(12)\end{array}$ & $\begin{array}{l}1.9 \pm 0.9 \\
(12)\end{array}$ & $\begin{array}{l}5.3 \pm 1.4 \\
(12)\end{array}$ & $\begin{array}{l}8.9 \pm 2.1 \\
(8)\end{array}$ \\
\hline \multicolumn{6}{|l|}{ MHS } \\
\hline Gracilis & $\begin{array}{l}0.12 \pm 0.2 \\
(6)\end{array}$ & $\begin{array}{l}0.78 \pm 0.5 \\
(6)\end{array}$ & $\begin{array}{l}1.6 \pm 1 \\
(6)\end{array}$ & $\begin{array}{l}7.5 \pm 3 \\
(6)\end{array}$ & $\begin{array}{l}13.7 \pm 1 \\
(6)\end{array}$ \\
\hline Trapezius & $\begin{array}{l}0.55 \pm 0.5 \\
(6)\end{array}$ & $\begin{array}{l}1.5 \\
(6)\end{array}$ & $\begin{array}{l}2.5 \pm 0.7 \\
(6)\end{array}$ & $\begin{array}{l}4.3 \pm 1.2 \\
(6)\end{array}$ & $17.8 \pm 8$ \\
\hline
\end{tabular}

*Values are means \pm standard deviation of mean; values in parenthesis are number of muscles tested.

that control trapezius muscle, compared to control gracilis, has greater contracture response to caffeine argues against but does not exclude this possibility.

The dynamic properties tested in gracilis and trapezius muscle indicate that each is a slow-type contractile muscle. This fact draws attention away from the physiological properties of the two muscles and centers on the difference in biochemical profiles as a probable explanation for the difference in contracture response to halothane or caffeine.

The cardinal feature of the results obtained in this experiment is the fact that variable biochemical functions among fiber types can markedly affect the quantitative contracture response to pharmacological agents. This observation is relevant for several reasons. The diagnosis of MHS in man is based upon the abnormal contracture response of human MHS muscle to caffeine and/or halothane. ${ }^{8}$ The possibility that various muscles may differ in biochemical constitution and thereby influence the contracture response draws attention to the necessity for biopsying the same muscle each time. The biopsied muscle probably should be evaluated for the relative proportions of the major fiber types. The possibility for various muscles to differ in biochemical constitution appears to be greater among animal species than in man. For this reason, uniform selection of muscle from the animal model (i.e. the pig) becomes paramount for comparative studies.

The present experiment did not determine if MHS is a feature of skeletal muscles composed predominantly of a single major fiber type or not. Halothane, not caffeine, is an agent which produces malignant hyperthermia in man. The contracture effect of halothane is conclusively greater in the MHS trapezius muscle which has a higher percentage of type 1 fibers. Halothane does not produce significant contracture in either trapezius or gracilis muscle from control pigs. Further experiments are necessary to determine if MHS inheritance is limited to muscle composed predominantly of type 1 myofibers.

\section{REFERENCES}

1. DenBorough, M.A. \& Lovell, R.R.H. Anaesthetic Deaths In a Family (Letter). Lancet 2: 45 (1960).

2. BRITT, B.A. \& Kalow, W. Malignant Hyperthemia: a Statistical Review. Can. Anaesth. Soc. J. 17: 293 (1970).

3. Denborough, M.A., King, J.O., Ebeling, P. \& ZAPF, P. Myopathy and Malignant Hyperpyrexia. Lancet $1: 1138$ (1970).

4. BRITT, B.A. \& KALOW, W. Malignant hyperthermia: Aetiology Unknown, Can. Anaesth. Soc. J. 17: 316 (1970).

5. Nelson, T.E., Jones, E.W, Venable, J.H. \& KeRR, D.D. Malignant Hyperthermia of Poland China Swine: Studies of a Myogenic Etiology. Anesthesiology 36: 52 (1972).

6. Kalow, W., Britt, B.A., Terreau, M.E. \& HaIsT, C. Metabolic Error of Muscle Metabolism After Recovery From Malignant Hyperthermia. Lancet 2: 895 (1970).

7. Moulds, R.F.W. \& Denborough, M.A. Biochemical Basis of Malignant Hyperpyrexia. $\mathrm{Br}$. Med. Jour. 2: 241 (1974).

8. NeLson, T.E., \& Flewellen, E.H. Malignant Hyperthermia: Diagnosis, Treatment \& Investi- 
gations of Skeletal Muscle Lesion. Texas Reports Biology and Medicine 38: 105 (1979).

9. Britt, B.A., Kalow, W., Gordon, A., HumPHREY, J.G. \& RewCastle, N.B. Malignant Hyperthermia: An Investigation of Five Patients. Can. Anaesth. Soc. J. 20:431 (1973).

10. Nelson, T.E., Bedell, D.M. \& JONES, E.W. Porcine malignant Hyperthermia Effects of Temperature and Extracellular Calcium Concentration on Halothane Induced Contracture of Susceptible Skeletal Muscle. Anesthesiology 42: 301 (1975).

11. Nelson, T.E. \& Denborough, M.A. Studies On Normal Skeletal Muscle In Relation To The Pathopharmacology of Malignant Hyperpyrexia. Clinical and Experimental Pharmacology and Physiology 4: 315 (1977).

12. NeLson, T.E. Excitation-Contraction Coupling. A Common Etiologic Pathway for Malignant Hyperthermia Susceptible Muscle. In Second International Symposium on Malignant Hyperthermia. Aldrete, J.A. and Britt, B.A., editors. Grune and Straton, New York, New York, 363 (1978).
13. Isaacs, H. \& Barlow, M.B. The Genetic Background To Malignant Hyperpyrexia Revealed by Serum Creatinine Phosphokinase Estimations In Asymptomatic Relatives. Br. Jour. Anaes. 42: 1077 (1970)

14. Ellis, F.R., Cain, P.A. \& Harkiman, D.G.F. Multifactorial Inheritance of Malignant Hyperthermia Susceptibility. In Second International Symposium on Malignant Hyperthermia. Aldrete, J.A., and Britt, B.A., editors. Grune and Straton, New York, New York, 329 (1978).

15. PadYKULA, H.A.\& GaUthier, G.F. In Exploratory Concepts in Muscular Dystrophy and Related Disorders. Milhorat, A.T., editor. Excerpta Medica, Amsterdam, 117 (1967).

16. Burke, R.E., Devine, D.N. \& Zajac, F.E. III Mammalian Motor Units: Physiological-Histochemical Correlation in Three Types in Cat Gut Gastrocnemius. Science 174: 709 (1971).

17. Pette, D. \& Spamer, C. Metabolic SubPopulations of Muscle Fibers: A Quantative Study. Diabetes 28: 25 (1979). 